Article

\title{
Tripodal Podand Ligand with a Superhalogen Nature as an Effective Molecular Trap
}

\author{
Adrianna Cyraniak and Marcin Czapla * \\ Laboratory of Quantum Chemistry, Department of Theoretical Chemistry, Faculty of Chemistry, University of \\ Gdańsk, Wita Stwosza 63, 80-308 Gdańsk, Poland; a.cyraniak.706@studms.ug.edu.pl \\ * Correspondence: marcin.czapla@ug.edu.pl
}

Received: 24 July 2020; Accepted: 25 August 2020; Published: 1 September 2020

\begin{abstract}
Tris(2-methoxyethyl) fluoroborate anion (TMEFA), anovel tripodal ligand based on the $\mathrm{BF}_{4}{ }^{-}$ superhalogen anion, is proposed and was investigated theoretically using ab initio MP2 (second-order Møller-Plesset perturbational method) and OVGF (outer valence Green function) methods. The studied molecule comprises three 2-methoxyethoxy groups $\left(-\mathrm{O}-\mathrm{CH}_{2}-\mathrm{CH}_{2}-\mathrm{O}-\mathrm{CH}_{3}\right)$ connected to a central boron atom, which results in the $\mathrm{C}_{3}$-symmetry of the compound. The resulting anion was stable against fragmentation processes and its vertical electron detachment energy was found to be $5.72 \mathrm{eV}$. Due to its equilibrium structure resembling that of classical tripodal podands, the $\left[\mathrm{F}-\mathrm{B}\left(\mathrm{O}-\mathrm{CH}_{2}-\mathrm{CH}_{2}-\mathrm{O}-\mathrm{CH}_{3}\right)_{3}\right]^{-}$ anion is capable of binding metal cations using its three arms, and thus may form strongly bound ionic complexes such as $\left[\mathrm{F}-\mathrm{B}\left(\mathrm{O}-\mathrm{CH}_{2}-\mathrm{CH}_{2}-\mathrm{O}-\mathrm{CH}_{3}\right)_{3}\right]^{-} / \mathrm{Li}^{+}$and $\left[\mathrm{F}-\mathrm{B}\left(\mathrm{O}-\mathrm{CH}_{2}-\mathrm{CH}_{2}-\mathrm{O}_{-}-\mathrm{CH}_{3}\right)_{3}\right]^{-} / \mathrm{Mg}^{2+}$. The binding energies predicted for such compounds far exceed those of the similar neutral classical podand ligands, which likely makes the $\left[\mathrm{F}-\mathrm{B}\left(\mathrm{O}-\mathrm{CH}_{2}-\mathrm{CH}_{2}-\mathrm{O}-\mathrm{CH}_{3}\right)_{3}\right]^{-}$system a more effective molecular trap or steric shielding agent with respect to selected metal cations.
\end{abstract}

Keywords: superhalogen anions; podand ligands; molecular trap

\section{Introduction}

Nearly 40 years ago, Gutsev and Boldyrev postulated the possible existence of chemical compounds characterized by very high electron affinity (EA) values exceeding that of the chlorine atom (3.62 eV [1]). Due to their unique electron-accepting properties, such species were termed "superhalogens" [2]. These unusual systems, initially described by a simple general formula $M X_{k+1}$ (where $M$ is a central atom surrounded by $k+1$ halogen ligands $X$, and $k$ stands for the maximal formal valence of $M$ ) [3], turned out to be capable of forming strongly bound and thermodynamically stable anions for which the vertical electron detachment energies (VDE) often exceeded $10 \mathrm{eV}[4,5]$ and approached $14 \mathrm{eV}$ in some cases [6,7]. It is worth mentioning that superhalogens were only studied theoretically until 1999, when the existence of certain representative superhalogen anions (i.e., $\mathrm{LiI}_{2}{ }^{-}, \mathrm{LiBr}_{2}{ }^{-}$, and $\mathrm{LiCl}_{2}{ }^{-}$) was finally confirmed experimentally by Wang's group [8]. Since then, superhalogens have been attracted attention and triggered numerous investigations related to their structures and properties. In particular, polynuclear superhalogens (containing more than one central atom $[9,10]$ ), alternative superhalogens (with nonhalogen ligands and/or nonmetal central atoms [11-15]), hyperhalogens (comprising a central atom and superhalogens acting as ligands) [16], mixed superhalogens (containing two different central atoms $[17,18]$ ), and certain anionic clusters with superhalogen natures (characterized by VDE values exceeding $14 \mathrm{eV}$ ) [7] have been described in the last 20 years. Regarding the applications of neutral superhalogens and their daughter anions, it should be mentioned that these compounds can act as strong oxidizers (with respect to atoms and molecules characterized by high ionization potential (IP) values) [19-23] and precursors of various superacids [24-33]. Furthermore, they play the electrolyte role in Li-ion batteries [34-36] and act as semiconductors in hybrid perovskite solar cells [37,38]. 
Classical superhalogen anions can also be useful as electronegative components of ionic liquids [39], whereas some high-symmetry compact structures may be utilized as steric shielding agents with respect to selected metal cations [40].

The ability to trap positively charged ions and thus protect them from contact with the chemical environment, and to introduce selected cations into various solutions are general features of certain complexes formed by crown ethers, cryptands, and podands [41-45]. In general, podands are acyclic supramolecular ligands and open-chain analogs of macrocyclic systems, with nonrigid structures containing heteroatoms embedded into their molecular "arms", which enables the complexation of various ions and neutral molecules [46,47]. Due to their rather flexible structure, podands have no preformed cavities, which in turn allows them to bind molecular guests of various sizes. On the other hand, their inherently open-ended structure results in a low selectivity of this process and lower stability of the complexes formed [48,49].

In this work, we demonstrated the possible use of a novel superhalogen anion (i.e., tris(2methoxyethyl) fluoroborate anion, which we have termed TMEFA) as an effective molecular trap with respect to selected metal ions. Taking into account both the podand-like shape of TMEFA and its excess negative charge, this superhalogen anion is expected to be capable of binding cations inside its three arms and thus forming strongly bound ionic complexes characterized by binding energy values significantly exceeding those of systems involving classical podands. We believe that our results will inspire further investigations concerning this new class of podands and their properties in the near future.

\section{Computational Methods}

The equilibrium molecular structures and the corresponding harmonic vibrational frequencies of the $\left[\mathrm{F}-\mathrm{B}\left(\mathrm{O}-\mathrm{CH}_{2}-\mathrm{CH}_{2}-\mathrm{O}-\mathrm{CH}_{3}\right)_{3}\right]^{-}$system (i.e., tris(2-methoxyethyl) fluoroborate anion), its ionic complexes with $\mathrm{Li}^{+}$and $\mathrm{Mg}^{2+}$ cations, and the analogous compounds formed by three arbitrarily chosen conventional tripodal podands (in order to compare the binding strength with respect to these cations) were calculated using the second-order Møller-Plesset (MP2) perturbational method [50,51] together with the Dunning's correlation consistent basis set of double-zeta quality augmented with a standard set of diffuse functions (aug-cc-pVDZ) [52-54].

Using the obtained equilibrium geometries, we applied the CBS-QB3 complete basis set method of Petersson and coworkers [55-57] to calculate the binding energies (BEs) between TMEFA and $\mathrm{Li}^{+}$ and $\mathrm{Mg}^{2+}$ cations and for the complexes containing typical podands. It should be noted that such calculated binding energies by definition involve zero-point energy corrections.

The thermodynamic stability of the tris(2-methoxyethyl) fluoroborate anion was verified through analysis of the Gibbs free energy value of the most probable fragmentation route (i.e., $\mathrm{F}^{-}$loss) which was obtained using the CBS-QB3 free energies (at T = 298.15 K) estimated for the structures optimized at the MP2/aug-cc-pVDZ theoretical level.

The vertical electron energy (VDE) value of TMEFA was evaluated at the OVGF/6-311++G (3df, 2pd) level for the MP2/aug-cc-pVDZ global minimum structure. The outer valence Green function OVGF method ( $B$ approximation) [58-63] together with analogous 6-311++G (3df, 2pd) basis sets was successfully used for various superhalogen anions in the past, and provided very good agreement with experimentally measured VDEs [9,64]. We also verified that the pole-strength (PS) value obtained for the TMEFA system was sufficiently large (PS $=0.91$ ) to justify the use of the OVGF approximation, because this method is valid only when the pole-strength values of the outer valence ionizations are larger than $0.80-0.85$ [65].

The Merz-Singh-Kollman scheme [66] was used to calculate the partial atomic charges. All calculations were performed with the GAUSSIAN16 (Rev.C.01) program package [67]. 


\section{Results}

\subsection{Structure and Stability of TMEFA}

The initial geometry of the tris(2-methoxyethyl) fluoroborate anion (TMEFA) was based on the tetrahedral $\mathrm{BF}_{4}{ }^{-}$superhalogen anion [68], in which three fluorine ligands were replaced with the 2-methoxyethoxy groups (i.e., $-\mathrm{O}-\mathrm{CH}_{2}-\mathrm{CH}_{2}-\mathrm{O}-\mathrm{CH}_{3}$ chains). The geometrical optimization of this initial structure resulted in the $\mathrm{C}_{3}$-symmetry equilibrium geometry of the TMEFA closed-shell monoanion depicted in Figure 1. As can be seen, this geometry is typical for tripodal podand ligands [46], which contain three identical open-ended chains linked together by a central atom (usually nitrogen or boron).
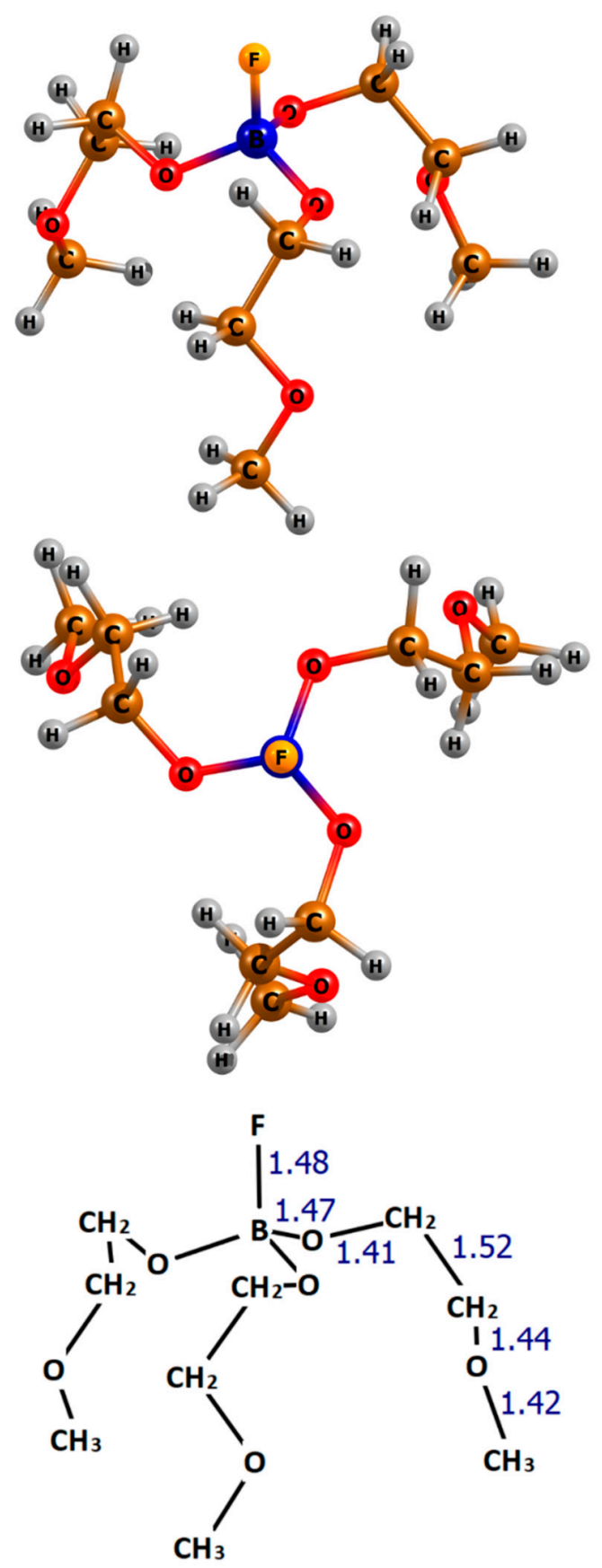

Figure 1. Equilibrium structure of the $\mathrm{C}_{3}$-symmetrical tris(2-methoxyethyl) fluoroborate anion (TMEFA). The bottom view shows the corresponding skeletal structure, with selected bond lengths given in $\AA$. 
As shown in Figure 1, the lengths of the F-B, B-O, O-C, C-C, C-O, and O-C bonds (listed consecutively according to their appearance in the F-B-O- $\mathrm{CH}_{2}-\mathrm{CH}_{2}-\mathrm{O}-\mathrm{CH}_{3}$ chain) were equal to $1.48 \AA$, $1.47 \AA, 1.41 \AA, 1.52 \AA, 1.44 \AA$, and $1.42 \AA$, respectively, while all C-H distances fell in the narrow 1.10-1.11 $\AA$ range. The F-B-O, B-O-C, O-C-C, C-C-O, and C-O-C valence angles were $108.7^{\circ}, 114.6^{\circ}$, $111.8^{\circ}, 109.4^{\circ}$, and $110.4^{\circ}$, respectively, whereas the F-B-O-O dihedral angle was $119.1^{\circ}$, which indicated the quasi-tetrahedral structure of the $\mathrm{FBO}_{3}$ fragment. Since the TMEFA system has an excess negative charge, it is expected that the six oxygen donor atoms form a negatively charged cavity inside the three chain substituents, which in turn should allow for effective cation complexation. The results of the Merz-Singh-Kollman analysis performed for TMEFA indicated that the partial atomic charges on each of the oxygen atoms connected with boron were equal to $-0.4 \mathrm{au}$, while the three remaining oxygen atoms held a negative charge of -0.3 au each. It should be emphasized that the partial atomic charge localized on the fluorine atom was also negative $(-0.5 \mathrm{au})$; hence, one might anticipate the formation of ionic complexes comprising TMEFA and a metal cation in which the latter is placed between the fluorine atom and one of the oxygen atoms (i.e., outside the cavity). For this reason, we verified that such isomeric complexes (i.e., containing the $\mathrm{F} \cdots \mathrm{M}^{+} \cdots \mathrm{O}$ fragment) indeed represented the energy minima; however, they were much higher in energy (by more than $25 \mathrm{kcal} / \mathrm{mol}$, which rendered their formation rather impossible under standard conditions) than the structures with metal ions bound inside the cavity (described in the following section).

In order to verify the thermodynamic stability of TMEFA against decomposition, we considered the only reasonable fragmentation path, namely, $\mathrm{F}^{-}$loss. The Gibbs free energy value estimated for this reaction was equal to $49.1 \mathrm{kcal} / \mathrm{mol}$ which confirmed the thermodynamic stability of the anion investigated. This means that the Gibbs free energy estimated for the opposite reaction, $\mathrm{B}\left(\mathrm{O}-\mathrm{CH}_{2}-\mathrm{CH}_{2}-\mathrm{O}-\mathrm{CH}_{3}\right)_{3}+\mathrm{F}^{-} \rightarrow\left[\mathrm{F}-\mathrm{B}\left(\mathrm{O}-\mathrm{CH}_{2}-\mathrm{CH}_{2}-\mathrm{O}-\mathrm{CH}_{3}\right)_{3}\right]^{-}$, was strongly negative, which indicates that $\mathrm{F}^{-}$could be spontaneously attached to tris(2-methoxyethyl) borate at room temperature. We also verified that this process could proceed with no kinetic barrier and thus may represent a potential route of TMEFA synthesis.

Since TMEFA is a negatively charged species, we also evaluated the excess electron-binding energy of this anion. The VDE of the $\left[\mathrm{F}-\mathrm{B}\left(\mathrm{O}-\mathrm{CH}_{2}-\mathrm{CH}_{2}-\mathrm{O}-\mathrm{CH}_{3}\right)_{3}\right]^{-}$system was calculated to be $5.72 \mathrm{eV}$, which confirmed its superhalogen nature; however, it should be mentioned that the vertical electronic stability of TMEFA was significantly lower than that of its $\mathrm{BF}_{4}{ }^{-}$precursor (VDE $=8.98 \mathrm{eV}$, as calculated at the same theory level [67]). Thus, our results were consistent with the previous investigations devoted to this subject which indicated that introducing various ligands into a conventional superhalogen anion reduces its VDE value [69].

Summing this section up, we concluded that the TMEFA anion adopts $\mathrm{C}_{3}$-symmetrical equilibrium structure and represents an electronically and thermodynamically stable system that is likely capable of acting as tripodal ligand with respect to metal cations.

\subsection{Complexes of TMEFA with $\mathrm{Li}^{+}$and $\mathrm{Mg}^{2+}$ Ions}

After describing the tris(2-methoxyethyl) fluoroborate anion, which has been identified as a podand ligand with a superhalogen nature, we now move on to the discussion of our results concerning its potential use as an effective molecular trap. As indicated in the introduction, such supramolecular systems are rather structurally flexible; thus, the cavity size predicted for isolated TMEFA does not necessarily correspond to that expected in complexes formed by TMEFA and metal cations. This anticipation is also supported by our earlier findings for another superhalogen anion, the structure of which resembles a molecular basket and captures guest atoms inside its cavity [39]. Hence, we decided to examine the complexation ability of the TMEFA system with respect to two arbitrarily selected metal ions with either +1 or +2 excess charge (i.e., $\mathrm{Li}^{+}$and $\mathrm{Mg}^{2+}$ ).

The equilibrium structures of the $\left[\mathrm{F}-\mathrm{B}\left(\mathrm{O}-\mathrm{CH}_{2}-\mathrm{CH}_{2}-\mathrm{O}-\mathrm{CH}_{3}\right)_{3}\right]^{-} / \mathrm{Li}^{+}$and $\left[\mathrm{F}-\mathrm{B}\left(\mathrm{O}-\mathrm{CH}_{2}-\mathrm{CH}_{2}-\mathrm{O}-\right.\right.$ $\left.\left.\mathrm{CH}_{3}\right)_{3}\right]^{-} / \mathrm{Mg}^{2+}$ ionic complexes are depicted in Figure 2. It needs to be emphasized that we limit our discussion herein to the lowest-energy structures of TMEFA/ $\mathrm{Li}^{+}$and TMEFA/ $\mathrm{Mg}^{2+}$ systems, as the 
relative energy values of other isomeric structures were found to be too large to be competitive with the global minima (see the preceding section).
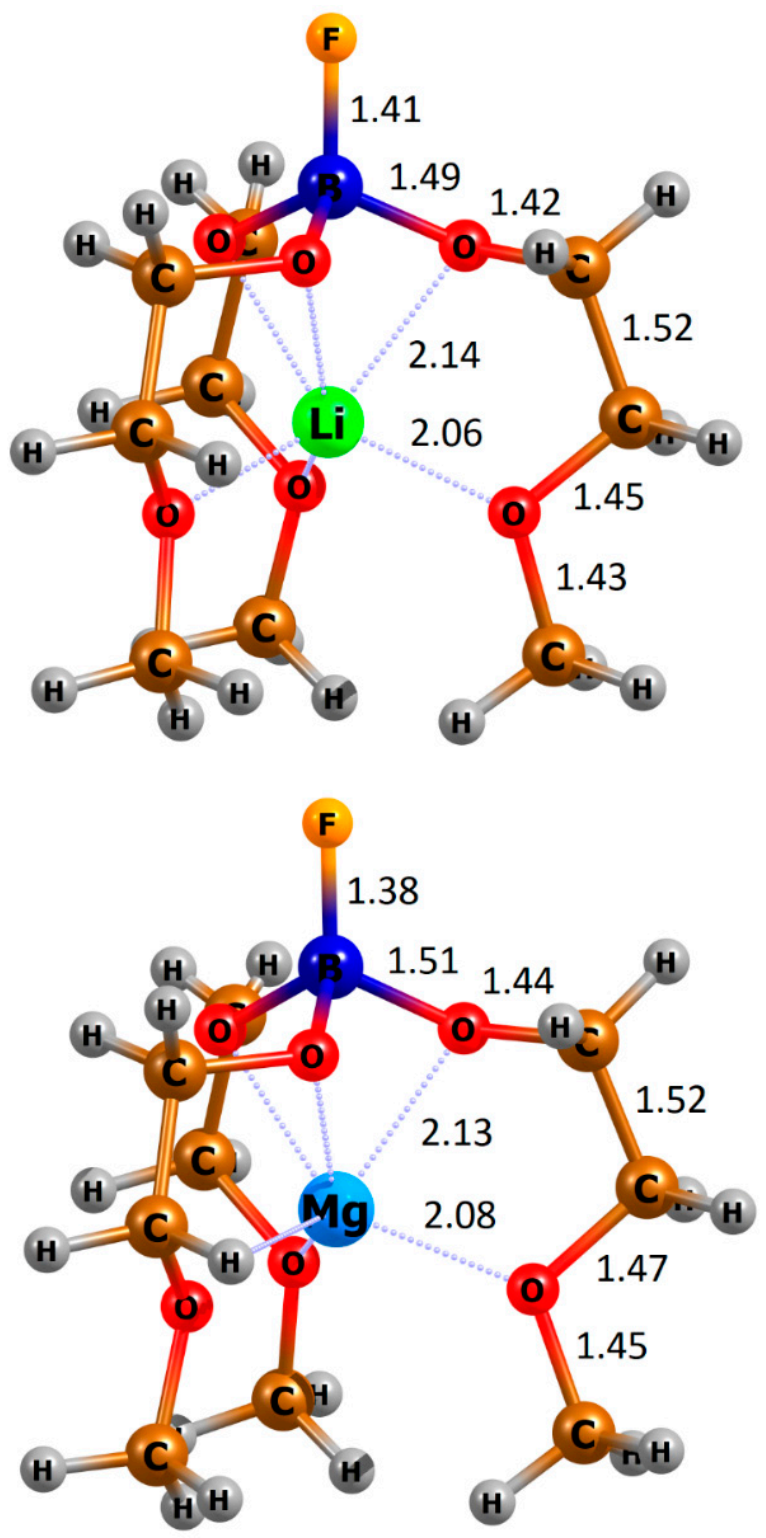

Figure 2. Equilibrium structures of the $\left[\mathrm{F}-\mathrm{B}\left(\mathrm{O}-\mathrm{CH}_{2}-\mathrm{CH}_{2}-\mathrm{O}-\mathrm{CH}_{3}\right)_{3}\right]^{-} / \mathrm{Li}^{+}$and $\left[\mathrm{F}-\mathrm{B}\left(\mathrm{O}-\mathrm{CH}_{2}-\mathrm{CH}_{2}-\mathrm{O}-\right.\right.$ $\left.\left.\mathrm{CH}_{3}\right)_{3}\right]^{-} / \mathrm{Mg}^{2+}$ ionic complexes. Selected interatomic distances are given in $\AA$.

The lowest energy isomers of the $\left[\mathrm{F}-\mathrm{B}\left(\mathrm{O}-\mathrm{CH}_{2}-\mathrm{CH}_{2}-\mathrm{O}-\mathrm{CH}_{3}\right)_{3}\right]^{-} / \mathrm{Li}^{+}$and $\left[\mathrm{F}-\mathrm{B}\left(\mathrm{O}-\mathrm{CH}_{2}-\mathrm{CH}_{2}-\mathrm{O}-\right.\right.$ $\left.\left.\mathrm{CH}_{3}\right)_{3}\right]^{-} / \mathrm{Mg}^{2+}$ complexes corresponded to $\mathrm{C}_{3}$-symmetrical structures with the metal cations localized on the $\mathrm{C}_{3}$-axis inside the cavities formed by the three molecular arms. As can be seen in Figure 2, due to the interactions between oxygen atoms and metal ions, the structures of the resulting compounds were more compact than that of isolated TMEFA ligand. The Li-O distances ( $2.06 \AA$ and $2.14 \AA$ ) and the $\mathrm{Mg}-\mathrm{O}$ separations ( $2.08 \AA$ and $2.13 \AA$ ) indicated that in both cases, the TMEFA acted as hexadentate podand ligand (i.e., a ligand forming six bonds with a guest atom). The F-B, B-O, O-C, C-C, C-O, and O-C bond lengths were only slightly changed in comparison to the isolated TMEFA anion described in the preceding section. In particular, the B-F distances in TMEFA/ $\mathrm{Mg}^{2+}$ and TMEFA/ $\mathrm{Li}^{+}$complexes were found to beshortened by $0.1 \AA$ and $0.07 \AA$, respectively, while all remaining bond lengths changed by less than $0.04 \AA$ (see Figures 1 and 2 for details). 
In order to verify whether the tris(2-methoxyethyl) fluoroborate anion might act as a molecular trap or play a steric shielding agent role, we decided to compare the binding energies (BE) of the complexes formed by TMEFA ligand to the BE values characterizing compounds involving three arbitrarily chosen (yet representative) tripodal podands. Two of these systems contained nitrogen as an anchor atom and two types of chains, namely $-\mathrm{O}-\mathrm{CH}_{2}-\mathrm{CH}_{2}-\mathrm{O}-\mathrm{CH}_{3}$ (as in the TMEFA ligand) and $-\mathrm{CH}_{2}-\mathrm{CH}_{2}-\mathrm{N}=\mathrm{CH}-\mathrm{CH}_{3}$, whereas the third compound contained boron as the central atom and $-\mathrm{CH}_{2}-\mathrm{CH}_{2}-\mathrm{N}=\mathrm{CH}-\mathrm{CH}_{3}$ groups. The schematic structures of these $\mathrm{N}\left(\mathrm{CH}_{2}-\mathrm{CH}_{2}-\mathrm{N}=\mathrm{CH}-\mathrm{CH}_{3}\right)_{3}$, $\mathrm{N}\left(\mathrm{O}-\mathrm{CH}_{2}-\mathrm{CH}_{2}-\mathrm{O}-\mathrm{CH}_{3}\right)_{3}$, and $\mathrm{B}\left(\mathrm{CH}_{2}-\mathrm{CH}_{2}-\mathrm{N}=\mathrm{CH}-\mathrm{CH}_{3}\right)_{3}$ podands and the equilibrium geometries of their ionic complexes formed with $\mathrm{Li}^{+}$and $\mathrm{Mg}^{2+}$ are depicted in Figure 3. Because the structural analysis of the isolated $\mathrm{N}\left(\mathrm{CH}_{2}-\mathrm{CH}_{2}-\mathrm{N}=\mathrm{CH}-\mathrm{CH}_{3}\right)_{3}, \mathrm{~N}\left(\mathrm{O}-\mathrm{CH}_{2}-\mathrm{CH}_{2}-\mathrm{O}-\mathrm{CH}_{3}\right)_{3}$, and $\mathrm{B}\left(\mathrm{CH}_{2}-\mathrm{CH}_{2}-\mathrm{N}=\mathrm{CH}-\mathrm{CH}\right)_{3}$ podands was not the main goal of this contribution, we have included only their skeletal formulas, whereas the Cartesian coordinates are available upon request.<smiles>CC=NCCN(CC/N=C\C)CCN/C(C)=C\C</smiles>

b
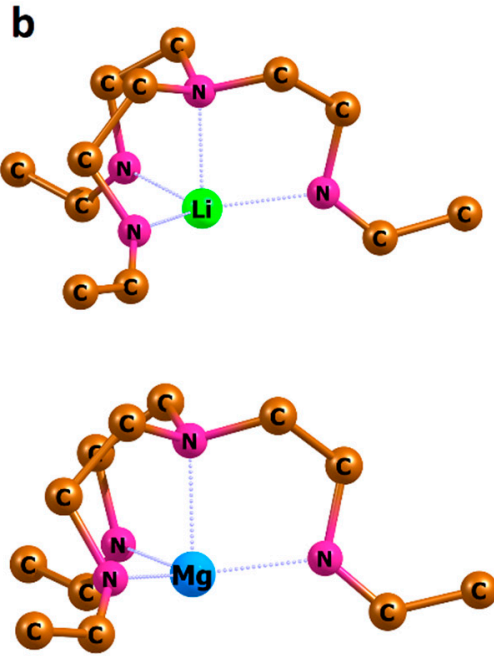<smiles>COCCON(OCCOC)OCCOC</smiles><smiles>CC=NCCB(CCN=CC)CCN=CC</smiles>
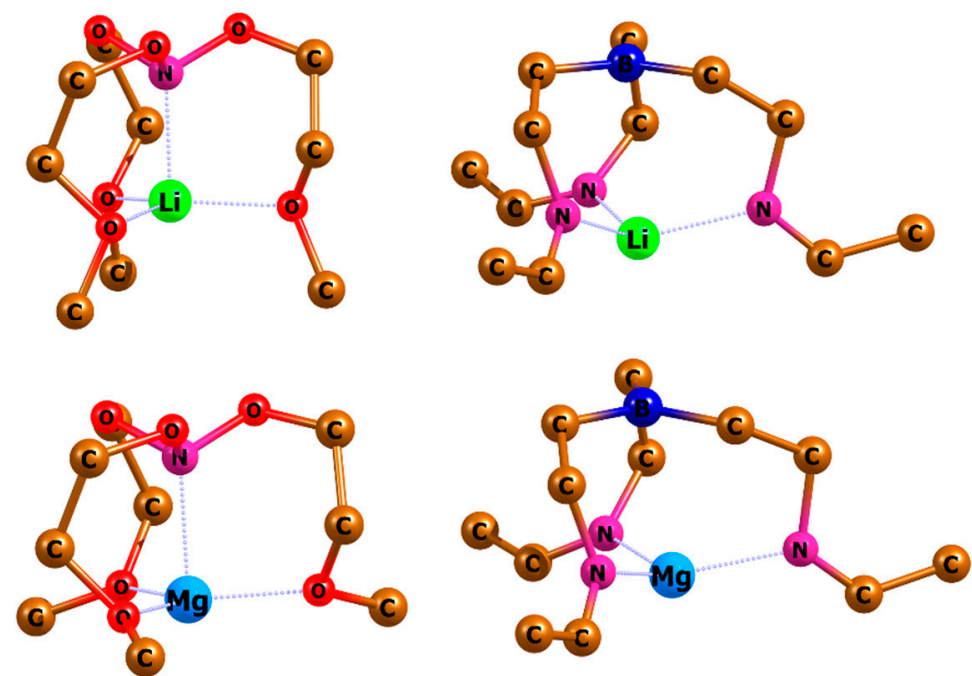

Figure 3. (a) Skeletal structural formulas of the systems chosen as representative classical podands. (b) Equilibrium structures of the ionic complexes formed by the three classical podands and $\mathrm{Li}^{+}$and $\mathrm{Mg}^{2+}$ cations. The hydrogen atoms are left out to make the pictures clearer.

According to our findings, the equilibrium structures of the $\mathrm{N}\left(\mathrm{O}-\mathrm{CH}_{2}-\mathrm{CH}_{2}-\mathrm{O}-\mathrm{CH}_{3}\right)_{3}$ compound and its complexes with $\mathrm{Li}^{+}$and $\mathrm{Mg}^{2+}$ exhibit $\mathrm{C}_{3}$-symmetry, while those involving $-\mathrm{CH}_{2}-\mathrm{CH}_{2}-\mathrm{N}=\mathrm{CH}-$ $\mathrm{CH}_{3}$ chains correspond to $\mathrm{C}_{1}$-symmetry (see Table 1 ). It should be emphasized that the $\mathrm{N}\left(\mathrm{CH}_{2}-\mathrm{CH}_{2}-\right.$ $\left.\mathrm{N}=\mathrm{CH}-\mathrm{CH}_{3}\right)_{3}$ and $\mathrm{N}\left(\mathrm{O}-\mathrm{CH}_{2}-\mathrm{CH}_{2}-\mathrm{O}-\mathrm{CH}_{3}\right)_{3}$ ligands are tetradentate, which means that they interact with $\mathrm{Li}^{+}$or $\mathrm{Mg}^{2+}$ ion by forming four dative bonds (i.e., involving their four atoms acting as lone-pair donors) (see Figure 3). On the other hand, the third podand considered (i.e., $\left.\mathrm{B}\left(\mathrm{CH}_{2}-\mathrm{CH}_{2}-\mathrm{N}=\mathrm{CH}-\mathrm{CH}_{3}\right)_{3}\right)$ has been found to act as a tridentate ligand, utilizing its three atoms as lone-pair donors, which in turn leads to the formation of complexes containing three dative bonds (Figure 3). The Li-N and Mg-N distances in $\left[\mathrm{N}\left(\mathrm{CH}_{2}-\mathrm{CH}_{2}-\mathrm{N}=\mathrm{CH}-\mathrm{CH}_{3}\right)_{3} \mathrm{Li}\right]^{+}$and $\left[\mathrm{N}\left(\mathrm{CH}_{2}-\mathrm{CH}_{2}-\mathrm{N}=\mathrm{CH}-\mathrm{CH}_{3}\right)_{3} \mathrm{Mg}\right]^{2+}$ systems fell in the ranges of 2.07-2.08 $\AA$ and 2.11-2.13 $\AA$, respectively, whereas the Li-N, Li-O, Mg-N, and Mg-O 
separations in the $\left[\mathrm{N}\left(\mathrm{O}-\mathrm{CH}_{2}-\mathrm{CH}_{2}-\mathrm{O}-\mathrm{CH}_{3}\right)_{3} \mathrm{Li}\right]^{+}$and $\left[\mathrm{N}\left(\mathrm{O}-\mathrm{CH}_{2}-\mathrm{CH}_{2}-\mathrm{O}-\mathrm{CH}_{3}\right)_{3} \mathrm{Mg}\right]^{2+}$ complexes were estimated to be $2.06 \AA, 1.94 \AA, 2.18 \AA$, and $1.99 \AA$, respectively. In addition, the tridentate systems containing $\mathrm{Li}^{+}$and $\mathrm{Mg}^{2+}$ were characterized by the $\mathrm{Li}-\mathrm{O}$ distances of $2.05 \AA$ and the $\mathrm{Mg}$-O distances of 2.09-2.11 $\AA$. These observations allowed us to conclude that the lengths of the $\mathrm{Li}-\mathrm{O}$ and $\mathrm{Mg}-\mathrm{O}$ dative bonds formed by typical tripodal podands were comparable to those predicted for the complexes involving TMEFA.

Table 1. Binding energies (Bes; calculated at the CBS-QB3//MP2/aug-cc-pVDZ level) characterizing the interactions between the podand ligands and $\mathrm{Li}^{+}$or $\mathrm{Mg}^{2+}$ cations embedded inside their cavities.

\begin{tabular}{ccc}
\hline Species & Symmetry & BE (kcal/mol) \\
\hline$\left[\mathrm{F}-\mathrm{B}\left(\mathrm{O}-\mathrm{CH}_{2}-\mathrm{CH}_{2}-\mathrm{O}-\mathrm{CH}_{3}\right)_{3}\right]^{-} / \mathrm{Li}^{+}$ & $\mathrm{C}_{3}$ & 180.1 \\
{$\left[\mathrm{~F}-\mathrm{B}\left(\mathrm{O}-\mathrm{CH}_{2}-\mathrm{CH}_{2}-\mathrm{O}-\mathrm{CH}_{3}\right)_{3}\right]^{-} / \mathrm{Mg}^{2+}$} & $\mathrm{C}_{3}$ & 457.3 \\
{$\left[\mathrm{~N}\left(\mathrm{O}-\mathrm{CH}_{2}-\mathrm{CH}_{2}-\mathrm{O}-\mathrm{CH}_{3}\right)_{3} \mathrm{Li}\right]^{+}$} & $\mathrm{C}_{3}$ & 81.5 \\
{$\left[\mathrm{~N}\left(\mathrm{O}-\mathrm{CH}_{2}-\mathrm{CH}_{2}-\mathrm{O}-\mathrm{CH}_{3}\right)_{3} \mathrm{Mg}\right]^{2+}$} & $\mathrm{C}_{3}$ & 246.5 \\
{$\left[\mathrm{~N}\left(\mathrm{CH}_{2}-\mathrm{CH}_{2}-\mathrm{N}=\mathrm{CH}-\mathrm{CH}_{3}\right)_{3} \mathrm{Li}\right]^{+}$} & $\mathrm{C}_{1}$ & 104.4 \\
{$\left[\mathrm{~N}\left(\mathrm{CH}_{2}-\mathrm{CH}_{2}-\mathrm{N}=\mathrm{CH}-\mathrm{CH}_{3}\right)_{3} \mathrm{Mg}\right]^{2+}$} & $\mathrm{C}_{1}$ & 297.6 \\
{$\left[\mathrm{~B}\left(\mathrm{CH}_{2}-\mathrm{CH}_{2}-\mathrm{N}=\mathrm{CH}-\mathrm{CH}_{3}\right)_{3} \mathrm{Li}\right]^{+}$} & $\mathrm{C}_{1}$ & 97.0 \\
{$\left[\mathrm{~B}\left(\mathrm{CH}_{2}-\mathrm{CH}_{2}-\mathrm{N}=\mathrm{CH}-\mathrm{CH}_{3}\right)_{3} \mathrm{Mg}\right]^{2+}$} & $\mathrm{C}_{1}$ & 273.0 \\
\hline
\end{tabular}

As far as the binding energy values showing the strengths of the cation-ligand interactions are concerned, we found them to be large for the complexes formed by TMEFA ligand (see Table 1). In particular, the $B E$ value of $180.1 \mathrm{kcal} / \mathrm{mol}$ estimated for $T M E F A / \mathrm{Li}^{+}$was much larger than the BEs calculated for the complexes formed by the $\mathrm{Li}^{+}$ion and the other podands considered $(\mathrm{BE}=81.5-104.4 \mathrm{kcal} / \mathrm{mol})$, while the $\mathrm{BE}$ of $457.3 \mathrm{kcal} / \mathrm{mol}$ predicted for $T M E F A / \mathrm{Mg}^{2+}$ greatly exceeded those evaluated for the complexes involving the $\mathrm{N}\left(\mathrm{CH}_{2}-\mathrm{CH}_{2}-\mathrm{N}=\mathrm{CH}-\mathrm{CH}_{3}\right)_{3}, \mathrm{~N}\left(\mathrm{O}-\mathrm{CH}_{2}-\mathrm{CH}_{2}-\mathrm{O}-\mathrm{CH}_{3}\right)_{3}$, and $\mathrm{B}\left(\mathrm{CH}_{2}-\mathrm{CH}_{2}-\mathrm{N}=\mathrm{CH}-\mathrm{CH}_{3}\right)_{3}$ podands and $\mathrm{Mg}^{2+}(\mathrm{BE}=246.5-297.6 \mathrm{kcal} / \mathrm{mol})$. Clearly, the excess negative charge of the TMEFA ligand is one of the main reasons for its much stronger interactions with the metal cations (manifested by large BE values) in comparison to the complexes containing neutral podands. Therefore, taking into account (i) the electronic and thermodynamic stability of the tris(2-methoxyethyl) fluoroborate ligand, (ii) the predicted ease of its synthesis, and (iii) its high affinity to the metal ions, we may draw the conclusion that the TMEFA represents a promising candidate for an effective molecular trap and a steric shielding agent to protect selected cations from the chemical environment.

\section{Conclusions}

The electronic and thermodynamic stability of the tris(2-methoxyethyl) fluoroborate anion (TMEFA), as well as its potential application as a molecular trap for $\mathrm{Li}^{+}$and $\mathrm{Mg}^{2+}$ cations, were investigated on the basis of ab initio quantum-chemical calculations carried out at the CBS-QB3//MP2/aug-cc-pVDZ and OVGF/6-311++G (3df, 2pd) theory levels. The results obtained led us to the following conclusions:

1. The TMEFA system is a strongly electronically bound anionic compound with a superhalogen nature, thermodynamically stable against decomposition reactions, whose vertical electron detachment energy was found to be $5.72 \mathrm{eV}$.

2. The equilibrium structure of TMEFA resembles those adopted by many well-known tripodal podand ligands, with a negatively charged cavity created by three open-ended 2-methoxyethoxy groups which allows for binding of selected metal ions $\left(\mathrm{Li}^{+}\right.$and $\left.\mathrm{Mg}^{2+}\right)$ inside the molecular "arms".

3. The examined ionic complexes formed by TMEFA, i.e., $\left[\mathrm{F}-\mathrm{B}\left(\mathrm{O}-\mathrm{CH}_{2}-\mathrm{CH}_{2}-\mathrm{O}-\mathrm{CH}_{3}\right)_{3}\right]^{-} / \mathrm{Li}^{+}$and [F-B $\left.\left(\mathrm{O}-\mathrm{CH}_{2}-\mathrm{CH}_{2}-\mathrm{O}-\mathrm{CH}_{3}\right)_{3}\right]^{-} / \mathrm{Mg}^{2+}$ systems, are characterized by large ligand-metal binding energies (180.1 and $457.3 \mathrm{kcal} / \mathrm{mol}$, respectively) that far exceed those predicted for the coordination complexes formed by other representative podands (either tetradentate or tridentate). 
4. Due to the anticipated ease of its synthesis and expected high affinity to various metal cations, TMEFA represents a promising novel podand ligand which might be utilized as an effective molecular trap and/or a steric shielding agent with respect to selected ions.

Author Contributions: Conceptualization, M.C.; methodology, M.C.; software, M.C.; validation, M.C. and A.C.; formal analysis, M.C. and A.C.; investigation, M.C. and A.C.; resources, M.C. and A.C.; data curation, M.C. and A.C.; writing-original draft preparation, M.C.; writing-review and editing, M.C.; visualization, M.C. and A.C.; supervision, M.C.; project administration, M.C.; funding acquisition, M.C. All authors have read and agreed to the published version of the manuscript.

Funding: This research was funded by the National Science Centre of Poland, grant number 2016/23/N/ST4/02556 and partially by the Polish Ministry of Science and Higher Education, grant number DS 31-T110-D499-20.

Acknowledgments: The calculations were performed using resources provided by Wroclaw Centre for Networking and Supercomputing (http://wcss.pl) Grant No. 350. Supported by the Foundation for Polish Science (FNP) (START 012.2019).

Conflicts of Interest: The authors declare no conflict of interest. The funders had no role in the design of the study; in the collection, analyses, or interpretation of data; in the writing of the manuscript, or in the decision to publish the results.

\section{References}

1. Hotop, H.; Lineberger, W.C. Binding energies in atomic negative ions: II. J. Phys. Chem. Ref. Data 1985, 14, 731-750. [CrossRef]

2. Gutsev, G.L.; Boldyrev, A.I. DVM-X $\alpha$ calculations on the ionization potentials of $\mathrm{MX}_{\mathrm{k}+1}{ }^{-}$complex anions and the electron affinities of $\mathrm{MX}_{\mathrm{k}+1}$ "superhalogens". Chem. Phys. 1981, 56, 277-283. [CrossRef]

3. Gutsev, G.L.; Boldyrev, A.I. The electronic structure of superhalogens and superalkalies. Russ. Chem. Rev. 1987, 56, 519-531. [CrossRef]

4. Sikorska, C.; Skurski, P. The saturation of the excess electron binding energy in $\mathrm{Al}_{n} \mathrm{~F}_{3 \mathrm{n}+1^{-}}(\mathrm{n}=1-5)$ anions. Chem. Phys. Lett. 2012, 536, 34-38. [CrossRef]

5. Sobczyk, M.; Sawicka, A.; Skurski, P. Theoretical search for anions possessing large electron binding energies. Eur. J. Inorg. Chem. 2003, 2003, 3790-3797. [CrossRef]

6. Freza, S.; Skurski, P. Enormously large (approaching $14 \mathrm{eV}$ !) electron binding energies of $\left[\mathrm{H}_{n} \mathrm{~F}_{\mathrm{n}+1}\right]^{-}(\mathrm{n}=1-5$, 7, 9, 12) anions. Chem. Phys. Lett. 2010, 487, 19-23. [CrossRef]

7. Czapla, M.; Ciepła, O.; Brzeski, J.; Skurski, P. Formation of enormously strongly bound anionic clusters predicted in binary superacids. J. Phys. Chem. A 2018, 122, 8539-8548. [CrossRef] [PubMed]

8. Wang, X.-B.; Ding, C.-F.; Wang, L.-S.; Boldyrev, A.I.; Simons, J. First experimental photoelectron spectra of superhalogens and their theoretical interpretations. J. Chem. Phys. 1999, 110, 4763-4771. [CrossRef]

9. Alexandrova, A.N.; Boldyrev, A.I.; Fu, Y.-J.; Yang, X.; Wang, X.-B.; Wang, L.-S. Structure of the $\mathrm{Na}_{\mathrm{x}} \mathrm{Cl}_{\mathrm{x}+1}{ }^{-}$ $(\mathrm{x}=1-4)$ clusters via ab initio genetic algorithm and photoelectron spectroscopy. J. Chem. Phys. 2004, 121, 5709-5719. [CrossRef]

10. Anusiewicz, I. $\mathrm{Mg}_{2} \mathrm{Cl}_{5}{ }^{-}$and $\mathrm{Mg}_{3} \mathrm{Cl}_{7}{ }^{-}$superhalogen anions. Aust. J. Chem. 2008, 61, 712-717. [CrossRef]

11. Smuczyńska, S.; Skurski, P. Is hydrogen capable of playing a central atom role in superhalogen anions? Chem. Phys. Lett. 2007, 443, 190-193. [CrossRef]

12. Gutsev, G.L. A theoretical investigation on the structure of the hypervalent carbon and silicon pentahalogenides as well as their singly charged anions. Chem. Phys. 1992, 166, 57-68. [CrossRef]

13. Smuczyńska, S.; Skurski, P. Halogenoids as ligands in superhalogen anions. Inorg. Chem. 2009, 48, 10231-10238. [CrossRef] [PubMed]

14. Anusiewicz, I. Superhalogen anions utilizing acidic functional groups as ligands. J. Phys. Chem. A 2009, 113, 11429-11434. [CrossRef] [PubMed]

15. Anusiewicz, I. Electrophilic substituents as ligands in superhalogen anions. J. Phys. Chem. A 2009, 113, 6511-6516. [CrossRef]

16. Paduani, C.; Wu, M.M.; Willis, M.; Jena, P. Theoretical study of the stability and electronic structure of $\mathrm{Al}\left(\mathrm{BH}_{4}\right)_{\mathrm{n}=1 \rightarrow 4}$ and $\mathrm{Al}^{-}\left(\mathrm{BF}_{4}\right)_{\mathrm{n}=1 \rightarrow 4}$ and their hyperhalogen behavior. J. Phys. Chem. A 2011, 115, 10237-10243. [CrossRef]

17. Czapla, M. Dinuclear superhalogen anions containing two different central atoms. J. Fluor. Chem. 2017, 199, 97-102. [CrossRef] 
18. Yang, H.; Li, Y.; He, H.-M.; Tong, J.; Wu, D.; Li, Z.-R. Superhalogen properties of hetero-binuclear anions $\mathrm{MM}^{\prime} \mathrm{F}_{4}{ }^{-}$and $\mathrm{MM}^{\prime \prime} \mathrm{F}_{5}{ }^{-}\left(\mathrm{M}=\mathrm{Li}, \mathrm{Na}, \mathrm{M}^{\prime}=\mathrm{Be}, \mathrm{Mg}, \mathrm{Ca} ; \mathrm{M}^{\prime \prime}=\mathrm{B}, \mathrm{Al}, \mathrm{Ga}\right)$. Chem. Phys. Lett. 2017, 684, 273-278. [CrossRef]

19. Sikorska, C.; Skurski, P. Moderately reactive molecules forming stable ionic compounds with superhalogens. Inorg. Chem. 2011, 50, 6384-6391. [CrossRef]

20. Marchaj, M.; Freza, S.; Rybacka, O.; Skurski, P. Superhalogen oxidizers capable of ionizing water molecules. Chem. Phys. Lett. 2013, 574, 13-17. [CrossRef]

21. Czapla, M.; Freza, S.; Skurski, P. Ionizing benzene with superhalogens. Chem. Phys. Lett. 2015, 619, 32-35. [CrossRef]

22. Czapla, M.; Skurski, P. Oxidizing $\mathrm{CO}_{2}$ with superhalogens. Phys. Chem. Chem. Phys. 2017, 19, 5435-5440. [CrossRef] [PubMed]

23. Sikorska, C. Oxidizing metal oxides with polynuclear superhalogen: An ab initio study. J. Phys. Chem. A 2018, 122, 7328-7338. [CrossRef] [PubMed]

24. Czapla, M.; Skurski, P. The existence and gas phase acidity of the $\mathrm{HAl}_{n} \mathrm{~F}_{3 \mathrm{n}+1}$ superacids $(\mathrm{n}=1-4)$. Chem. Phys. Lett. 2015, 630, 1-5. [CrossRef]

25. Czapla, M.; Skurski, P. Strength of the Lewis-Brønsted superacids containing In, Sn, and Sb and the electron binding energies of their corresponding superhalogen anions. J. Phys. Chem. A 2015, 119, 12868-12875. [CrossRef] [PubMed]

26. Srivastava, A.K.; Misra, N. Hydrogenated superhalogens behave as superacids. Polyhedron 2015, 102, 711-714. [CrossRef]

27. Czapla, M.; Anusiewicz, I.; Skurski, P. Does the protonation of superhalogen anions always lead to superacids? Chem. Phys. 2016, 465-466, 46-51. [CrossRef]

28. Srivastava, A.K.; Kumar, A.; Misra, N. Superhalogens as building blocks of a new series of superacids. New J. Chem. 2017, 41, 5445-5449. [CrossRef]

29. Srivastava, A.K.; Kumar, A.; Misra, N. A path to design stronger superacids by using superhalogens. J. Fluor. Chem. 2017, 197, 59-62. [CrossRef]

30. Zhou, F.-Q.; Xu, W.-H.; Li, J.-F.; Zhao, R.-F.; Yin, B. The combination of superhalogens and Brønsted acids HX $(\mathrm{X}=\mathrm{F}, \mathrm{Cl}, \mathrm{Br})$ : An effective strategy for designing strong superacids. Inorg. Chem. 2017, 56, 11787-11797. [CrossRef] [PubMed]

31. Anusiewicz, I.; Freza, S.; Skurski, P. Stability of the $\mathrm{Ti}_{n} \mathrm{~F}_{4 \mathrm{n}+1}{ }^{-}$and $\mathrm{Ge}_{\mathrm{n}} \mathrm{F}_{4 \mathrm{n}+1}{ }^{-}$superhalogen anions and the acidity of the $\mathrm{HTi}_{n} \mathrm{~F}_{4 \mathrm{n}+1}$ and $\mathrm{HGe}_{\mathrm{n}} \mathrm{F}_{4 \mathrm{n}+1}(\mathrm{n}=1-3)$ superacids. Polyhedron 2018, 144, 125-130. [CrossRef]

32. Zhao, R.F.; Zhou, F.-Q.; Xu, W.; Li, J.F.; Li, C.-C.; Li, J.; Yin, B. Superhalogen-based composite with strong acidity: A crossing point between two topics. Inorg. Chem. Front. 2018, 5, 2934-2947. [CrossRef]

33. Brzeski, J.; Czapla, M.; Skurski, P. Icosahedral carborane superacids and their conjugate bases comprising $\mathrm{H}$, $\mathrm{F}, \mathrm{Cl}$, and $\mathrm{CN}$ substituents: A theoretical investigation of monomeric and dimeric cages. ChemPlusChem 2020, 85, 312-318. [CrossRef]

34. Sikorska, C. Magnesium-based clusters as building blocks of electrolytes in lithium-ion batteries. ChemPhysChem 2019, 20, 2236-2246. [CrossRef] [PubMed]

35. Giri, S.; Behera, S.; Jena, P. Superhalogens as building blocks of halogen-free electrolytes in lithium-ion batteries. Angew. Chem. Int. Ed. 2014, 53, 13916-13919. [CrossRef]

36. Jena, P. Superhalogens: A bridge between complex metal hydrides and Li ion batteries. J. Phys. Chem. Lett. 2015, 6, 1119-1125. [CrossRef]

37. Fang, H.; Jena, P. Super-ion inspired colorful hybrid perovskite solar cells. J. Mater. Chem. A 2016, 4, 4728-4737. [CrossRef]

38. Fang, H.; Jena, P. Molecular origin of properties of organic-inorganic hybrid perovskites: The big picture from small clusters. J. Phys. Chem. Lett. 2016, 7, 1596-1603. [CrossRef]

39. Welton, T. Room-temperature ionic liquids. Solvents for synthesis and catalysis. Chem. Rev. 1999, 99, 2071-2084. [CrossRef]

40. Czapla, M. Polynuclear $\mathrm{Li}_{12} \mathrm{~F}_{13}{ }^{-}$anion as a steric shielding agent with respect to selected metal ions. Theor. Chem. Acc. 2016, 135, 1-8. [CrossRef]

41. Blair, S.M.; Brodbelt, J.S.; Marchand, A.P.; Chong, H.S.; Alihodžić, S. Evaluation of alkali metal binding selectivities of caged aza-crown ether ligands by microelectrospray ionization/quadrupole ion trap mass spectrometry. J. Am. Soc. Mass Spectrom. 2000, 11, 884-891. [CrossRef] 
42. Kumondai, K.; Toyoda, M.; Ishihara, M.; Katakuse, I.; Takeuchi, T.; Ikeda, M.; Iwamoto, K. Experimental and theoretical study on gas-phase ion/molecule reactions of silver trimer cation, $\mathrm{Ag}^{+}$, with 12-crown-4. J. Chem. Phys. 2005, 123, 024314. [CrossRef] [PubMed]

43. Inokuchi, Y.; Ebata, T.; Ikeda, T.; Haino, T.; Kimura, T.; Guo, H.; Furutani, Y. New insights into metal ion-crown ether complexes revealed by SEIRA spectroscopy. New J. Chem. 2015, 39, 8673-8680. [CrossRef]

44. Allen, O.R.; Field, L.D.; Magill, A.M.; Vuong, K.Q.; Bhadbhade, M.M.; Dalgarno, S.J. Ruthenium complexes of CP3: A new carbon-centered polydentate podand ligand. Organometallics 2011, 30, 6433-6440. [CrossRef]

45. Inoue, Y. Cation Binding by Macrocycles: Complexation of Cationic Species by Crown Ethers; CRC Press: New York, NY, USA, 1990.

46. Weber, E. Encyclopedia of Supramolecular Chemistry; Atwood, J.L., Steed, J.W., Eds.; Taylor \& Francis: Boca Raton, MA, USA, 2004; p. 1106.

47. Weber, E.; Vögtle, F. Classification and nomenclature of coronands, cryptands, podands, and of their complexes. Inorg. Chim. Acta 1980, 45, L65-L67. [CrossRef]

48. Gierczyk, B.; Pankiewicz, R. Supramolecular complexes of podand ligands with xenon. Cent. Eur. J. Chem. 2014, 12, 624-634. [CrossRef]

49. Filby, M.H.; Steed, J.W. A modular approach to organic, coordination complex and polymer based podand hosts for anions. Coord. Chem. Rev. 2006, 250, 3200-3218. [CrossRef]

50. Head-Gordon, M.; Pople, J.A.; Frisch, M.J. MP2 energy evaluation by direct methods. Chem. Phys. Lett. 1988, 153, 503-506. [CrossRef]

51. Frisch, M.J.; Head-Gordon, M.; Pople, J.A. Direct MP2 gradient method. Chem. Phys. Lett. 1990, 166, $275-280$. [CrossRef]

52. Dunning, T.H., Jr. Gaussian basis sets for use in correlated molecular calculations. I. The atoms boron through neon and hydrogen. J. Chem. Phys. 1989, 90, 1007-1023. [CrossRef]

53. Kendall, R.A.; Dunning, T.H., Jr. Electron affinities of the first-row atoms revisited. Systematic basis sets and wave functions. J. Chem. Phys. 1992, 96, 6796-6806. [CrossRef]

54. Woon, D.E.; Dunning, T.H., Jr. Gaussian-basis sets for use in correlated molecular calculations. 3. The atoms aluminum through argon. J. Chem. Phys. 1993, 98, 1358-1371. [CrossRef]

55. Petersson, G.A.; Bennett, A.; Tensfeldt, T.G.; Al-Laham, M.A.; Shirley, W.A.; Mantzaris, J. A complete basis set model chemistry. I. The total energies of closed-shell atoms and hydrides of the first-row atoms. J. Chem. Phys. 1998, 89, 2193-2218. [CrossRef]

56. Montgomery, J.A., Jr.; Ochterski, J.W.; Petersson, G.A. A complete basis set model chemistry. IV. An improved atomic pair natural orbital method. J. Chem. Phys. 1994, 101, 5900-5909. [CrossRef]

57. Petersson, G.A.; Tensfeldt, T.G.; Montgomery, J.A., Jr. A complete basis set model chemistry. III. The complete basis set-quadratic configuration interaction family of methods. J. Chem. Phys. 1991, 94, 6091-6101. [CrossRef]

58. Zakrzewski, V.G.; Ortiz, J.V.; Nichols, J.A.; Heryadi, D.; Yeager, D.L.; Golab, J.T. Comparison of perturbative and multiconfigurational electron propagator methods. Int. J. Quantum Chem. 1996, 60, 29-36. [CrossRef]

59. Simons, J. Direct calculation of first- and second-order density matrices. The higher RPA method. J. Chem. Phys. 1971, 55, 1218-1230. [CrossRef]

60. Ortiz, J.V. Electron binding energies of anionic alkali metal atoms from partial fourth order electron propagator theory calculations. J. Chem. Phys. 1988, 89, 6348-6352. [CrossRef]

61. Cederbaum, L.S. One-body Green's function for atoms and molecules: Theory and application. J. Phys. B At. Mol. Phys. 1975, 8, 290-303. [CrossRef]

62. Zakrzewski, V.G.; Ortiz, J.V. Semidirect algorithms for thirdorder electron propagator calculations. Int. J. Quantum Chem. 1995, 53, 583-590. [CrossRef]

63. Simons, J.; Smith, W.D. Theory of electron affinities of small molecules. J. Chem. Phys. 1973, 58, $4899-4907$. [CrossRef]

64. Sikorska, C.; Ignatowska, D.; Freza, S.; Skurski, P. The performance of selected ab initio methods in estimating electron binding energies of superhalogen anions. J. Theor. Comput. Chem. 2011, 10, 93-109. [CrossRef]

65. Zakrzewski, V.G.; Dolgounitcheva, O.; Ortiz, J.V. Ionization energies of anthracene, phenanthrene, and naphthacene. J. Chem. Phys. 1996, 105, 8748-8753. [CrossRef]

66. Besler, B.H.; Merz, K.M., Jr.; Kollman, P.A. Atomic charges derived from semiempirical methods. J. Comput. Chem. 1990, 11, 431-439. [CrossRef] 
67. Frisch, M.J.; Trucks, G.W.; Schlegel, H.B.; Foresman, J.B.; Fox, D.J. Gaussian 16, Revision C.01; Gaussian, Inc.: Wallingford, CT, USA, 2019.

68. Sikorska, C.; Smuczyńska, S.; Skurski, P.; Anusiewicz, I. $\mathrm{BX}_{4}{ }^{-}$and $\mathrm{AlX}_{4}{ }^{-}$superhalogen anions $(\mathrm{X}=\mathrm{F}, \mathrm{Cl}, \mathrm{Br})$ : An ab initio study. Inorg. Chem. 2008, 47, 7348-7354. [CrossRef] [PubMed]

69. Smuczyńska, S.; Skurski, P. Introducing various ligands into superhalogen anions reduces their electronic stabilities. Chem. Phys. Lett. 2008, 452, 44-48. [CrossRef] 